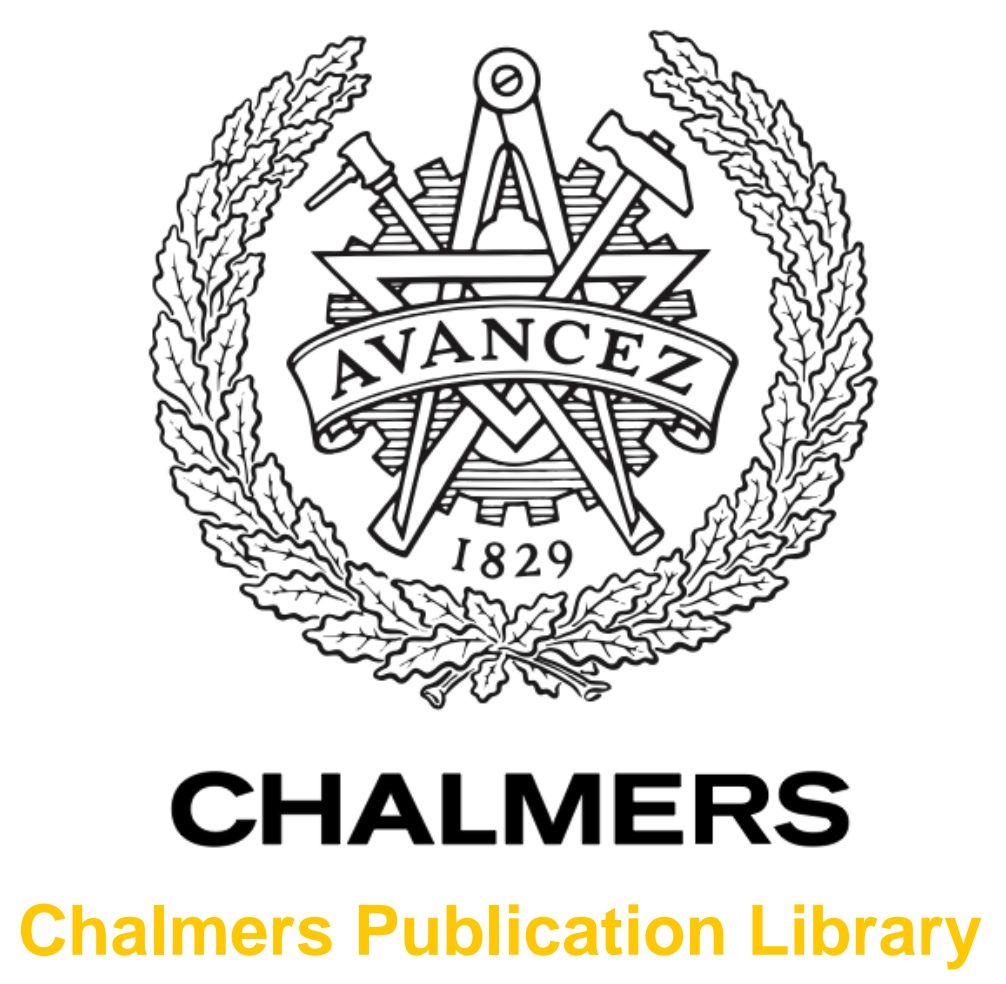

\title{
Critical Factors for Quality Management Initiatives in Small and Medium-Sized Enterprises
}

This document has been downloaded from Chalmers Publication Library (CPL). It is the author's version of a work that was accepted for publication in:

Total Quality Management \& Business Excellence (ISSN: 1478-3371)

\footnotetext{
Citation for the published paper:

Assarlind, M. ; Gremyr, I. (2014) "Critical Factors for Quality Management Initiatives in Small and Medium-Sized Enterprises". Total Quality Management \& Business Excellence, vol. 25(4), pp. 397-411.
}

http://dx.doi.org/10.1080/14783363.2013.851330

Downloaded from: http://publications.lib.chalmers.se/publication/186970

Notice: Changes introduced as a result of publishing processes such as copy-editing and formatting may not be reflected in this document. For a definitive version of this work, please refer to the published source. Please note that access to the published version might require a subscription. 


\title{
Critical Factors for Quality Management Initiatives in Small and Medium-Sized Enterprises
}

\author{
Marcus Assarlind* and Ida Gremyr \\ Division of Quality Sciences, Chalmers University of Technology \\ *marcus.assarlind@chalmers.se
}

This is an Author's Accepted Manuscript of an article published in Total Quality Management \& Business Excellence, 12 Nov 2013, available online: http://www.tandfonline.com/10.1080/14783363.2013.851330.

\begin{abstract}
This paper identifies critical factors for Quality Management (QM) initiatives in small and medium-sized enterprises (SMEs). The factors are grouped into six categories: Contextualization; Gradual implementation using realistic goals; Involvement and training of employees; Involvement of external support; Management Involvement; and Fact-based follow-up. A further analysis of the literature indicates that well-recognized ideas for improvement in large companies are useful for SMEs as well. However, compared to large companies more focus is needed on acquiring external support, planning for a QM initiative in line with characteristics of the specific SME, and planning for a gradual implementation of the QM initiative that is followed up by realistic goals.
\end{abstract}

Keywords: Quality Management, Small and Medium-Sized Enterprises, Critical factors

\section{Introduction}

Quality Management (QM) has grown into a mature research field (Sousa \& Voss, 2002). It has become widely acknowledged and is often, in some form or another, incorporated in the daily operations of large companies. QM can be described as an approach to management that is based on certain reinforcing principles, as well as related practices and hands-on techniques (Dean \& Bowen, 1994). QM is based on principles concerning cooperation and learning, process management, continuous improvement, and a focus on enhancing customer as well as employee satisfaction (Anderson et al., 1994).

Historically, QM research has predominantly been focusing on large companies (Beheshti \& Lollar, 2003; Demirbag et al., 2006; Kuratko et al., 2001; Thomas \& Webb, 2003b; Yusof \& Aspinwall, 1999). While large companies are important, small and medium-sized enterprises (SMEs) are as crucial to national economies; constituting the majority of all companies and jobs (e.g. European Commission, 2008; Ghobadian \& Gallear, 1997; Gunasekaran et al., 2000; van der Wiele \& Brown, 1998). This calls for special attention towards the conditions of SMEs. Even though there are different views on the differentiating characteristics of SMEs (e.g. Bridge et al., 2003; Ghobadian \& Gallear, 1996; Yusof \& Aspinwall, 2000c), there is a common view that they function differently from large companies. 
One of the reasons why SMEs should work with QM is that they often serve as suppliers to large companies; demanding the SMEs to work with QM. Ghobadian and Gallear (1997, p. 125) pointed out that QM in SMEs "is not restricted to the relationship with larger customer firms. Adoption of [QM] can help SMEs manage the transition from the incubation stage to the maturity stage effectively". Ghobadian and Gallear (1996, p. 161) argued that "the basic concepts of [QM] were equally applicable to the SME context. However, the detail and method of implementation differed”. In line with this reasoning, Hansson and Klefsjö (2003), as well as Davig et al. (2003) argued that adoption rather than the concept itself constitutes a major challenge to QM and that it is crucial to adapt QM to the context in which it will be used.

Even though the incentives are considerable, QM has not yet to any significant degree been adopted in smaller companies (Achanga et al., 2006). However, studies have suggested that recent initiatives related to QM can be adopted in both large and small companies (Kumar \& Antony, 2008). A QM initiative refers to intentional efforts involving QM principles and practices. For it to be an initiative, and not only isolated improvement projects, these efforts should be meant to be sustaining and part of a larger plan. Based on a review of the literature, the purpose of this paper is to identify critical factors for QM initiatives in SMEs. With inspiration from Saraph et al. (1989), a critical factor for QM is defined as a critical area of managerial planning and action that should be considered in order to achieve effective QM in a company. In the following, the method applied will be discussed. The remainder of the paper is devoted to analysis and discussion of the findings from the literature review.

\section{Method}

In terms of conceptual goal, this review aims at explicating (MacInnis, 2011) critical factors related to Quality Management in SMEs by summarizing, or clustering, the identified critical factors. This section has three parts; one on the paper selection, a second on coding of papers, and a third on extracting the critical factors.

\subsection{Selection of Papers}

The literature reviewed in this paper was primarily identified through searches in three databases: Emerald Insight, Proquest and ISI Web of Science. The search terms used were SME (or Small and Medium Sized Enterprise, depending on the predefined word in each database) and quality. The latter was chosen to cover Quality Management as well as parallel notions such as Total Quality Management or Quality Practices.

The articles included in the analysis mainly focused on the manufacturing industry; literature dealing with mixed industry types is included. However, literature that focuses solely on service industry has not been reviewed since previous research points to differences between the service and manufacturing industries in the area of QM (for a review see Rönnbäck \& Witell, 2008). Literature focusing on the implementation of computer-based systems to support QM, or specific methods, such as Design of Experiments or Statistical Process Control, has been disregarded as the focus is on QM overall. In addition papers focusing Six Sigma have been excluded as such an initiative has been identified as different from QM in e.g. training programs and organisational structures (Schroeder et al., 2008). 
The authors jointly selected the relevant papers by reading titles and abstracts. If an author judged a paper as relevant and the other did not, the reasons were discussed until consensus could be reached. In the following step, the full texts of the papers were considered. See Figure 1 for an overview of the selection process.

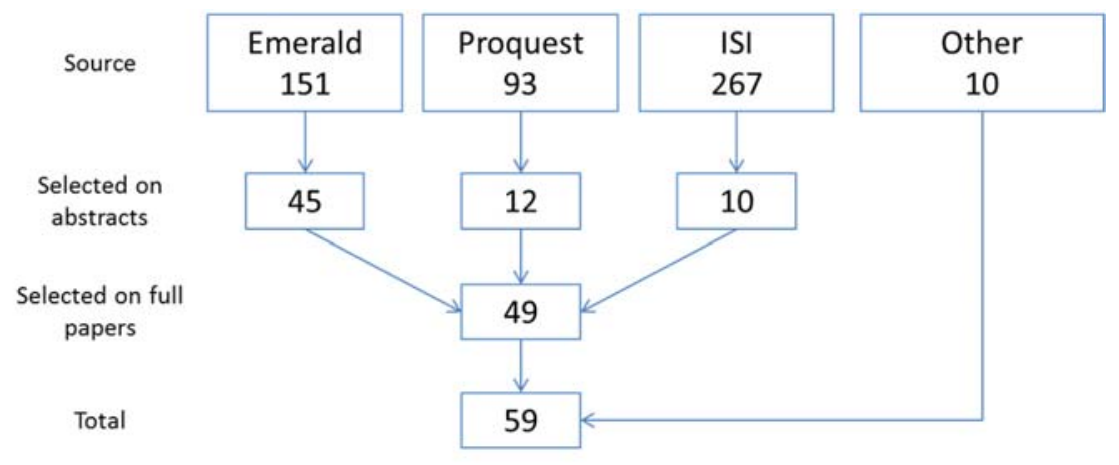

Figure 1: The paper selection process

Apart from structured database searches, directed searches were conducted in SME-focused journals, such as Journal of Small Business Management and International Small Business Journal. Finally, papers have been identified through a so-called "snowball technique": trailing citations in other relevant papers. While there is a high dispersion of journals (24 different outlets in total), the two journals Total Quality Management \& Business Excellence and International Journal of Quality \& Reliability Management together account for one third of the papers with 13 and 8 papers, respectively.

\subsection{Coding of literature}

In addition to basic citation data, each selected article was coded by the type of study, data sources, research outcomes and the use of literature (inspired by Barratt et al., 2011 and shown in Table 1). Regarding "Research Outcomes", descriptive insights means that the article describes the empirical data and indicates conclusions; "Proposition" means normative guidelines, particularly for the practice of QM, but also conceptual guidelines; and "Framework" means general step-by-step ideas for QM implementation.

Table 1: Coding of the papers, factors besides basic citation data (year of publication, title, authors, and journal.)

\begin{tabular}{|ll|}
\hline Coding Criteria & Possible values \\
\hline Type of study & Case, Multiple case, Survey, Review, Conceptual \\
\hline Data sources & Interviews, Observations, Participation, Literature, Documents, Survey \\
\hline Research outcomes & Descriptive insight, Proposition, Framework \\
\hline Use of literature & Develop constructs, examine findings, framing, abductive, review \\
\hline
\end{tabular}

The coding of each article was conducted by either author; in cases of difficulty in coding, the article was coded by the other author as well. In cases when an article showed multiple characteristics within a criterion, the main characteristic was chosen. If, for example, an article reviewed literature and conducted a small case study in order to develop a survey, the type of study 
was coded as a survey. The majority of all articles are surveys. Overall, most articles provide descriptive insight or propositions.

It is noteworthy that few articles use single cases, and that twelve of 59 articles are based on multiple case studies. Of these twelve papers, eight are based on interviews, while the remaining multiple case studies are based on participation (three) and observations (one). Furthermore, by cross-referencing the type of article with the Outcome, of the four articles that provide frameworks, three are conceptual and one results from a multiple case study, while none results from surveys (Figure 2). Surveys, by far the most common type, equally often result in descriptive insight or propositions, but never in frameworks.

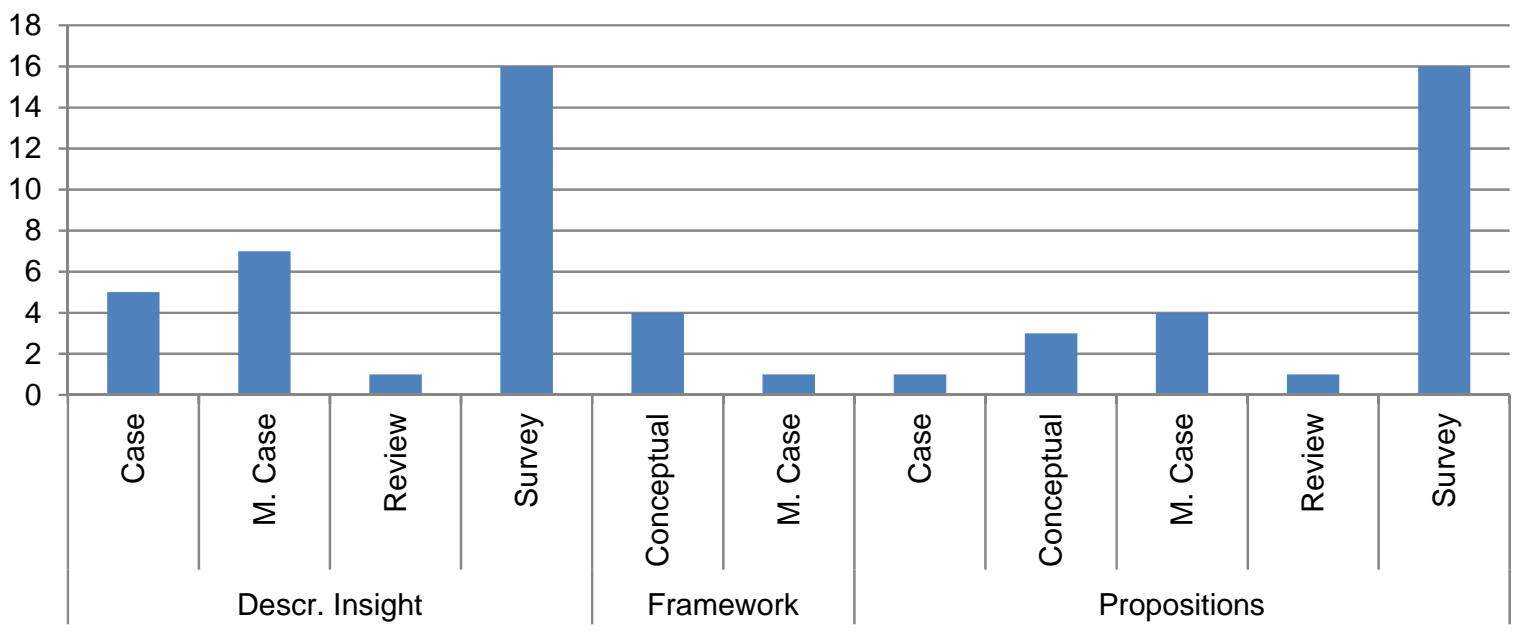

Figure 2: Outcome of article stratified by Type of article

\subsection{Extraction and Categorization of Critical Factors}

Each paper was assigned to one of the authors, who extracted the critical factors by using the definition: a critical area of managerial planning and action that should be considered in order to achieve effective QM in a company. As a first step of categorization, about 30 critical factors were extracted from the first 10 read papers, and described on sticky notes and grouped. The categorization of the factors was based on a joint construction of an affinity diagram, i.e. "a graphical brainstorming tool, used to group facts, opinions, ideas and customer desires according to some form of natural affinity" (Shahin et al., 2010, p. 187). Each category was subsequently assigned a descriptive label. This initial categorization is visualised in Figure 3. This step was followed by extraction of factors from the remaining papers. These additional factors were continuously matched against the initial categorization, and the categories were thus continuously discussed and revised; a process closely resembling pattern matching as described by Yin (2009).

In both steps of the categorization, certain factors that could be attributed to more than one category were discussed among the authors to reach a common view on their essential meaning. Finally, individual factors unique to one reference that did not fit into any category were left out of the analysis. These factors were less than five in total and were related to specific tools, for example the proposition of the required use of design of experiments. 


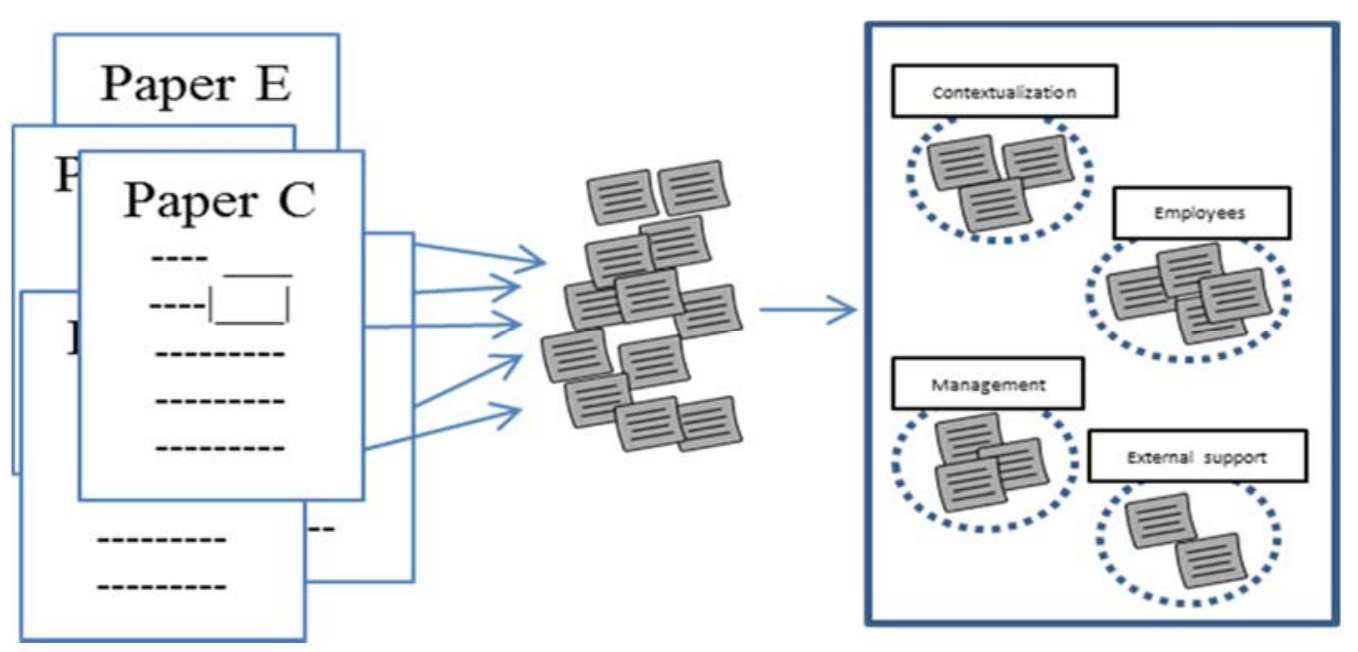

Figure 3: Initial extraction and categorization of critical factors

\section{Investigating Quality Management adoption in SMEs}

The first part of this section contrasts SMEs vis-à-vis large companies. The major part of this section subsequently presents a categorisation of critical factors for QM initiatives aimed at SMEs.

\subsection{Characteristics of SMEs}

The official European quantitative definition of SMEs refers to companies with 0-250 employees that are independent of large companies (European Commission, 2008). SMEs can also be qualitatively defined, see e.g. Hollander (1967) who views companies as SMEs if they do not exceed a size that permits personalised management, while still containing most business functions in-house. While it is obvious that there might be vast differences between individual SMEs, there are some common characteristics that distinguish SMEs from large companies. An adaptation of attempts (Ahire \& Golhar, 1996; Bridge et al., 2003) to describe such characteristics is shown in Table 2.

Table 2: SME characteristics (adapted from Ghobadian \& Gallear, 1997; Hudson et al., 2001)

\begin{tabular}{|c|c|c|c|}
\hline Structure & Contact & Processes & People \\
\hline $\begin{array}{l}\text { - Flat structure with few layers } \\
\text { of management } \\
\text { - Large degree of influence } \\
\text { exercised by individual } \\
\text { managers } \\
\text { - Informal strategies } \\
\text { - Single sited } \\
\text { - Potential for quick responses } \\
\text { to external changes } \\
\text { - Low degree of specialisation } \\
\text { - Unified culture } \\
\text { - Limited financial resources }\end{array}$ & $\begin{array}{l}\text { - Operating in limited } \\
\text { markets with a small } \\
\text { customer base } \\
\text { - Limited external contacts }\end{array}$ & $\begin{array}{l}\text { - Flexible processes } \\
\text { - Low degree of } \\
\text { standardisation } \\
\text { - Reactive and fire } \\
\text { fighting mentality } \\
\text { - Result-oriented }\end{array}$ & $\begin{array}{l}\text { - Modest human capital } \\
\text { and know-how } \\
\text { - Very few internal } \\
\text { change catalysts } \\
\text { - Individuals can see the } \\
\text { results of their efforts } \\
\text { - Low incidence of } \\
\text { unionisation }\end{array}$ \\
\hline
\end{tabular}


As outlined in Table 2, the characteristics of SMEs have been clustered into structure, contact, processes and people. Examples of structural and contact characteristics include the limited size of SMEs which intrinsically means that they are often single-sited and operate in limited markets. Furthermore, "SMEs are more likely to be 'people-oriented' than 'system-oriented"” (Ghobadian \& Gallear, 1997, p. 131), which among other things can be said to lead to flat structures, flexible processes, and reactive mentalities. SMEs often lack financial resources as well as resources in terms of human capital and internal know-how.

\subsection{Critical factors}

There are six main factor categories: Contextualization, Gradual implementation using realistic goals, Involvement and training of employees, Involvement of external support, Management Involvement, and Fact-based follow-up. Table 3 provides an explanatory sentence per category and displays the articles underlying each of the categories.

\subsubsection{Contextualization}

An important aspect of applying QM in SMEs is the need to contextualise to the characteristics of SMEs (Yusof \& Aspinwall, 2000a), as well as to the unique needs of each company (Yusof \& Aspinwall, 2000d). As noted by (Ghobadian \& Gallear, 1996, p. 86), "Differences exist in structure, policy making procedures, and utilisation of resources to the extent that the application of large business concepts directly to small businesses may border on the ridiculous.”

Customer focus is a central principle in QM (Dean \& Bowen, 1994). SMEs are often attributed a profound, albeit implicit, customer focus (Danes et al., 2008). Hodgetts et al. (1999) nevertheless emphasised the need for an explicit focus (including data gathering and data analysis), in order to move from being reactive to proactive in the area of customer needs and customer complaints. In other words, an SME should stick to its profound customer focus but making it explicit, perhaps by using it as a base for organising and contextualizing its QM work (Hansson \& Klefsjö, 2003).

The QM initiative should not be something separate or apart from remaining company processes; to the contrary, it is important to connect it to the existing company goals (M. N. A. Rahman \& Tannock, 2005; Salaheldin, 2009; Thomas \& Webb, 2003b). The focus needs to remain on the core business. In line with this, a first crucial step for a QM initiative is to identify the needs of the company (Ghobadian \& Gallear, 1997; Hansson \& Klefsjö, 2003; Tannock et al., 2002) in order to arrive at goals for the QM initiative that are realistic and achievable (Ghobadian \& Gallear, 1997; Thomas \& Webb, 2003b).

\subsubsection{Gradual implementation using realistic goals}

The literature suggests gradual and systematic implementation of QM with close monitoring (Ghobadian \& Gallear, 1997; Struebing \& Klaus, 1997; Yusof \& Aspinwall, 2000d). The approach should, perhaps naturally, be cost-effective with a focus on the most strategic issues (Salaheldin, 2009; Thomas \& Webb, 2003b). This is especially true at the start, when the initiative must show early profits (Yusof \& Aspinwall, 2000d). Early profits are desirable not only in order to adhere to resource constraints but also as a step towards engendering trust in the initiative. In this way, the QM initiative can prove itself at every step, in some cases even using saved money to sponsor upcoming projects. 
Table 3: Synthesis of critical factors for QM initiatives in SMEs, numbers within parentheses in the category column indicate number of references per category.

\begin{tabular}{|c|c|}
\hline Category & References \\
\hline $\begin{array}{l}\text { Contextualization (14) } \\
\text { A QM implementation adapted to fit the specific } \\
\text { company and its characteristics, e.g. building on } \\
\text { the company's current strengths. }\end{array}$ & $\begin{array}{l}\text { Boon and Ram (1998); Ghobadian and Gallear (1996, 1997); } \\
\text { Hansson and Klefsjö (2003); Hodgetts et al. (1999); Jones et } \\
\text { al. (2005); Martínez-Costa and Jiménez-Jiménez (2009); M. } \\
\text { N. A. Rahman and Tannock (2005); Salaheldin (2009); } \\
\text { Tannock et al. (2002); Temtime (2003); Temtime and } \\
\text { Solomon (2002); Thomas and Webb (2003); Yusof and } \\
\text { Aspinwall (2000a, 2000d) }\end{array}$ \\
\hline $\begin{array}{l}\text { Gradual implementation using realistic goals } \\
\text { (15) } \\
\text { A step-wise QM implementation with continuous } \\
\text { monitoring to show its benefits and show early } \\
\text { profit. }\end{array}$ & $\begin{array}{l}\text { Ahmed and Hassan (2003); Fening et al. (2008); Ghobadian } \\
\text { and Gallear (1996, 1997); Hansson and Klefsjö (2003); } \\
\text { Hodgetts et al. (1999); C. Y. Lee (2004); Neerland and } \\
\text { Kvalfors (2000); Ryan and Moss (2005); Struebing and Klaus } \\
\text { (1997); Temtime (2003); Temtime and Solomon (2002); } \\
\text { Thomas and Webb (2003); Yusof and Aspinwall (2000a, } \\
\text { 2000d) }\end{array}$ \\
\hline $\begin{array}{l}\text { Involvement and training of employees (30) } \\
\text { Employee involvement can be reinforced by } \\
\text { information and communication, training, in } \\
\text { addition to recognition and rewards of } \\
\text { accomplished QM work. }\end{array}$ & $\begin{array}{l}\text { Abdul-Aziz et al. (2000); Ahmed and Hassan (2003); } \\
\text { Beheshti and Lollar (2003); Boon and Ram (1998); Chandler } \\
\text { and McEvoy (2000); Chileshe (2007); Claver and Tarí (2008); } \\
\text { Davig et al. (2003); Demirbag, Tatoglu, et al. (2006); } \\
\text { Gadenne and Sharma (2009); Ghobadian and Gallear (1996, } \\
\text { 1997); Hodgetts et al. (1999); Khalid et al. (2011); Kumar and } \\
\text { Antony (2008); Kuratko et al. (2001); C. Y. Lee (2004); Lewis } \\
\text { et al. (2006b); Neerland and Kvalfors (2000); M. N. A. } \\
\text { Rahman and Tannock (2005); S.-U. Rahman (2001); Ryan } \\
\text { and Moss (2005); Salaheldin (2009); Sun and Cheng (2002); } \\
\text { Temtime (2003); Temtime and Solomon (2002); Thomas and } \\
\text { Webb (2003); van der Wiele and Brown (1998); Yusof and } \\
\text { Aspinwall (1999, 2000a, 2000b) }\end{array}$ \\
\hline $\begin{array}{l}\text { Involvement of external support (7) } \\
\text { External support might be required e.g. to } \\
\text { educate or employ a person with QM skills to } \\
\text { support the implementation. }\end{array}$ & $\begin{array}{l}\text { Ahlström-Söderling (2003); Fening et al. (2008); Ghobadian } \\
\text { and Gallear (1996); G. L. Lee and Oakes (1995); Neerland and } \\
\text { Kvalfors (2000); M. N. A. Rahman and Tannock (2005); } \\
\text { Thomas and Webb (2003) }\end{array}$ \\
\hline $\begin{array}{l}\text { Management Involvement (24) } \\
\text { Management has a role to spread an awareness } \\
\text { and understanding of QM to support the } \\
\text { implementation. }\end{array}$ & $\begin{array}{l}\text { Beheshti and Lollar (2003); Boon and Ram (1998); Chileshe } \\
\text { (2007); Davig et al. (2003); Fening et al. (2008); Gadenne and } \\
\text { Sharma (2009); Ghobadian and Gallear (1996); Hansson and } \\
\text { Klefsjö (2003); Hodgetts et al. (1999); Jones et al. (2005); C. } \\
\text { Y. Lee (2004); Lewis et al. (2006b); Neerland and Kvalfors } \\
\text { (2000); S.-U. Rahman (2001); Ryan and Moss (2005); } \\
\text { Salaheldin (2009); R. K. Singh (2011); Sun and Cheng } \\
\text { (2002); Tannock et al. (2002); Temtime (2003); Temtime and } \\
\text { Solomon (2002); Thomas and Webb (2003); van der Wiele } \\
\text { and Brown (1998); Yusof and Aspinwall (1999, 2000a, } \\
\text { 2000c) }\end{array}$ \\
\hline $\begin{array}{l}\text { Fact-based follow-up (14) } \\
\text { Measuring the impact of QM to ensure that } \\
\text { actions are in alignment with the goals, and that } \\
\text { improvements are made. }\end{array}$ & $\begin{array}{l}\text { Davig et al. (2003); Demirbag, Tatoglu, et al. (2006); } \\
\text { Gadenne and Sharma (2009); Hodgetts et al. (1999); Kuratko } \\
\text { et al. (2001); Lewis et al. (2006b); S.-U. Rahman (2001); } \\
\text { Ryan and Moss (2005); Salaheldin (2009); Struebing and } \\
\text { Klaus (1997); Sun and Cheng (2002); Tannock et al. (2002); } \\
\text { van der Wiele and Brown (1998); Yusof and Aspinwall } \\
\text { (2000c) }\end{array}$ \\
\hline
\end{tabular}


QM is not a quick fix. Several authors have pointed out that there must be realistic goals concerning time, costs and results (Ghobadian \& Gallear, 1997; Struebing \& Klaus, 1997). By setting unrealistic goals, business managers risk creating a situation where expectations exceed achievements (Ghobadian \& Gallear, 1996); "small organizations must realize that although they should see some immediate results, the greater benefits are slower in coming” (Struebing \& Klaus, 1997, p. 25).

\subsubsection{Involvement and training of employees}

General strengths of SMEs are high degree of employee involvement and a management that is close to its employees (Ahire \& Golhar, 1996; Ghobadian \& Gallear, 1997). The involvement of all employees in implementing QM is often argued to be critical to SMEs (Beheshti \& Lollar, 2003; Salaheldin, 2009; van der Wiele \& Brown, 1998); or as stated by (Claver \& Tarí, 2008, p. 207): "training and staff are basic elements of quality improvement". Three broad themes regarding this aspect are addressed in previous research: information and communication, training and recognition, and rewards of QM work.

In order to create involvement, a common practice is to ensure that information on the initiative is spread (M. N. A. Rahman \& Tannock, 2005). Further, to an employee, the feeling of being wellinformed is a basis for feeling empowered, thus lessening the fears of impending changes (Hodgetts et al., 1999; Kumar \& Antony, 2008). This notion is expressed by M. N. A. Rahman and Tannock (2005, p. 501) as follows: "Management must aim primarily to create a conducive environment for team spirit and open communication with employees, to work together towards achieving the common goals of the company.” To support open communication, Boon and Ram (1998, p. 34) describe a communication forum that was established in a company with the benefits described by an employee: "Previously, continuous improvement was done individually, not collectively. We had to learn the same lesson over and over again. Now, a problem is solved once throughout the company."

As QM encompasses principles, practices and techniques (Dean \& Bowen, 1994), it is often associated with the most "tangible" element: the techniques. However, training can encompass all three areas and represents an important means of involving employees by ensuring the availability of necessary capabilities and by transforming the new ways of working into standard company practice (Yusof \& Aspinwall, 2000a). Davig et al. (2003) advocated the need for company-wide training programmes; however, it has also been argued that an SME must account for the cost of training of all staff members and make a sound judgement of the level of training needed (Hodgetts et al., 1999). However, others argue that it is unfeasible for an SME with limited resources to perform training of all employees (Thomas \& Webb, 2003b).

Finally, empirical studies of QM in SMEs point to the importance of rewards and recognition of employees contributing to QM (Demirbag et al., 2006; Kuratko et al., 2001; M. N. A. Rahman \& Tannock, 2005). Examples are given of both individual and team-based rewards (Kuratko et al., 2001); covering suggestion schemes with associated monetary rewards, certification or promotion programmes (M. N. A. Rahman \& Tannock, 2005). Noteworthy, however, is the on-going discussion regarding the sometimes counter-productive results of monetary rewards (e.g. Pink, 2010; Robinson \& Schroeder, 2006). 


\subsubsection{Involvement of external support}

Smaller companies tend to face scarcity of resources (Jones et al., 2005b). For example, a company with only a dozen employees might find it hard to free up an employee to work full-time on QM, let alone educating or employing someone with these skills (Yusof \& Aspinwall, 2000d). However, government bodies may be willing to provide external backing (G. L. Lee \& Oakes, 1995; M. N. A. Rahman \& Tannock, 2005).

Various ways of acquiring external support have been suggested. A common recommendation is to cooperate across company borders (Ahlström-Söderling, 2003; Thomas \& Webb, 2003b). Such cooperation can be either horizontal (companies with similar processes and conditions) or vertical (companies in the same supply chain) (Ahlström-Söderling, 2003). Once resources have been secured (from, for example, the government and/or a consortium of SMEs), Thomas and Webb (2003b) suggest that training should be performed en masse by university educational institutes. Thomas and Webb further advised against relying on consultants as skills and knowledge might be lost to the company when the consultants move on to the next assignment.

\subsubsection{Management involvement}

Ghobadian and Gallear (1997) point out that management visibility is an inherently strong feature of SMEs. Visible management involvement in QM can be manifested in different ways, e.g. through the provision of resources. Yusof and Aspinwall (2000a) proposed establishing a central coordinating body of senior managers harmonising the QM initiative, e.g. by reviewing and measuring its progress. However, establishing such a coordinating body might prove challenging in an SME context facing a scarcity of resources (Ahire \& Golhar, 1996; Jones et al., 2005b; Yusof \& Aspinwall, 2000d).

In many SMEs it is critical to convince management of the benefits of QM (van der Wiele \& Brown, 1998). In an implementation model for QM in small companies, Hansson and Klefsjö (2003) emphasised the need to start working with a committed leadership before starting to use specific tools supportive of QM. A committed leadership does not only bring about sufficient resources, but can also publically show continuous attention to QM activities (Beheshti \& Lollar, 2003; Hodgetts et al., 1999; Tannock et al., 2002). The provision of management support is not, however, always tied to financial resources; as stated by Beheshti and Lollar (2003, p. 841), the "lack of adequate resources might actually help a company implement quality by focusing on the key business drivers”.

Managers who have understood the possibilities of QM can initiate the implementation process by linking QM to specific company needs, taking on the role of establishing a "change attitude" (Hansson \& Klefsjö, 2003). Tannock et al. (2002) argued that many times, managers' understanding of their role with regard to QM is limited. The management of an SME is very influential; "In SMEs an enlightened top management could readily implement far reaching change. On the other hand a backward looking top management could effectively block progress indefinitely” (Ghobadian \& Gallear, 1996, p. 104).

\subsubsection{Fact-based follow-up}

Learning from the QM efforts of other companies is useful (Salaheldin, 2009; Struebing \& Klaus, 1997; Tannock et al., 2002). Struebing and Klaus (1997) argued that such an endeavour can involve 
learning from other SMEs but also from larger companies. However, learning from one's own efforts involve, among others, internal data collection, making sure operations are aligned with goals and measuring the impact of QM (Kuratko et al., 2001; Salaheldin, 2009; van der Wiele \& Brown, 1998). To allow for fact-based follow-up collection of basic data, such as cost, sales, net income and market share, as well as customer satisfaction data is needed (Hodgetts et al., 1999; Kuratko et al., 2001). The data collection is important in order to improve internal processes and customer satisfaction (Davig et al., 2003), and to have facts supporting actual improvements (Demirbag et al., 2006).

\section{Discussion}

Despite the fact that the QM literature has traditionally been focusing mainly on large companies, researchers argue that QM could be fruitfully adopted in a beneficial way also in SMEs. At the same time, such adoption is seldom viewed as a trivial task. Based on the literature reviewed, this section discusses critical factors involving QM initiatives with theoretical as well as managerial implications.

\subsection{Theoretical Implications}

By and large, the categories of factors critical to SMEs, such as the involvement of employees and management, are quite similar to those discussed in conventional, non-SME-focused QM frameworks (such as those of Bergman \& Klefsjö, 2010; Dean \& Bowen, 1994). However, in relation to QM, it is surprising that the QM literature pertaining to SMEs barely contains any emphasis on customer focus, which is usually at the centre of attention in the broad QM literature. A possible explanation is that this principle, although not evident in the critical factors, is often implicit in the research since small companies are often organised around the idea of servicing customers; "these small companies are very customer-focused, and several of the managers explain that the customer is most important for the company because it is the customer who pays for their existence. There is 'no business without the customers'” (Rantakyrö, 2004, p. 92). Further, the Contextualisation category is often given greater prominence than in conventional QM frameworks (Bergman \& Klefsjö, 2010; Dean \& Bowen, 1994), which might be symptomatic of the diversity of the SME group. Finally, it appears that these frameworks (Bergman \& Klefsjö, 2010; Dean \& Bowen, 1994) do not explicitly adress the following categories: Involvement of External Support, Contextualisation, and Gradual Implementation Using Realistic Goals.

The categories of critical factors identified in this paper include some conflicts. First, Davig et al. (2003) argued that it is always vital to launch company-wide initiatives to train all employees, while Hodgetts et al. (1999) felt that such training should only apply to a limited number of cases and areas. This might be mitigated by, for example, choosing a smaller unit of the company and by making sure that everyone in that unit has at least a rudimentary understanding of QM (Hodgetts et al., 1999; Kumar \& Antony, 2008; M. N. A. Rahman \& Tannock, 2005). Second, there is agreement on the importance of involving senior management. However, there is a potential conflict with regard to how this issue should be handled. Yusof and Aspinwall (2000a) proposed establishing a central coordinating body running all QM activities. However, insufficient resources are a common denominator of SMEs (Ahire \& Golhar, 1996; Jones et al., 2005b) and to get a sufficient number of managers involved in such a body may prove challenging. Third, with respect to the Involvement and Training of Employees category, there is a need for sensible judgment regarding monetary rewards for QM activities. Such ideas have proven beneficial in some contexts 
but it is possible that similar interventions in other cultural contexts (national or organisational) may prove counterproductive (Robinson \& Schroeder, 2006).

\subsection{Managerial Implications}

As SMEs share characteristics unique to them, rather than trying to copy QM practices of large companies, adaptations based on the categories of critical factors identified in the literature review are needed. In Table 4, the categories of critical factors are rephrased as advice for anyone about to start a QM initiative in an SME.

Table 4. Categories of critical factors and related advice for successful QM initiatives

\begin{tabular}{|c|c|}
\hline Category & Advice \\
\hline $\begin{array}{l}\text { Contextualisation } \\
\text { QM implementation adapted to fit the specific company } \\
\text { and its characteristics, e.g. building on the current } \\
\text { strengths of the company. }\end{array}$ & $\begin{array}{l}\text { - Set goals for QM initiative based on company goals } \\
\text { - Make customer focus explicit } \\
\text { - Align QM initiative with current business goals and } \\
\text { practices }\end{array}$ \\
\hline $\begin{array}{l}\text { Gradual Implementation Using Realistic Goals } \\
\text { A step-wise QM implementation with continuous } \\
\text { monitoring to demonstrate its benefits and show early } \\
\text { profit. }\end{array}$ & $\begin{array}{l}\text { - Establish realistic goals based on awareness that } \\
\text { QM is not a quick fix } \\
\text { - Start with a small pilot project with potential for } \\
\text { success } \\
\text { - Expand stepwise from one area without doing } \\
\text { everything at once }\end{array}$ \\
\hline $\begin{array}{l}\text { Involvement and Training of Employees } \\
\text { Employee involvement can be reinforced by information, } \\
\text { communication and training, in addition to recognition } \\
\text { and rewards for accomplished QM work. }\end{array}$ & $\begin{array}{l}\text { - Train employees in QM practices } \\
\text { - Establish forums to offer plentiful information and } \\
\text { communication } \\
\text { - Reward (not necessarily in monetary terms) } \\
\text { involvement in the QM initiative }\end{array}$ \\
\hline $\begin{array}{l}\text { Involvement of External Support } \\
\text { External support might be required, e.g. educating or } \\
\text { employing an individual with QM skills to support QM } \\
\text { implementation. }\end{array}$ & $\begin{array}{l}\text { - Search for external support (e.g. government } \\
\text { agencies) } \\
\text { • Establish networks of other organisations for mutual } \\
\text { support }\end{array}$ \\
\hline $\begin{array}{l}\text { Management Involvement } \\
\text { Management has the role to spread awareness and } \\
\text { understanding of QM to support its implementation. }\end{array}$ & $\begin{array}{l}\text { - Ensure continuous attention from management } \\
\text { • Establish coordinating body } \\
\text { - Make sure management is showing public support } \\
\text { for the QM initiative }\end{array}$ \\
\hline $\begin{array}{l}\text { Fact-Based Follow-Up } \\
\text { Measuring the impact of QM to ensure that company } \\
\text { actions are in alignment with planned improvements. }\end{array}$ & $\begin{array}{l}\text { - Benchmark with other companies and organisations } \\
\text { - Collect data from internal processes to be able to } \\
\text { follow up on QM efforts }\end{array}$ \\
\hline
\end{tabular}

While the advice compiled in this article is geared towards SME needs, it should be emphasised that it does not exclude validity for large companies. As seen in the section on theoretical implications, there are overlaps between factors applicable to large companies and those applicable to SMEs. As outlined in Table 2, unique SME characteristics have been identified in previous research and grouped into Structure, Contacts, Processes, and People. A focus on Contextualisation in SMEs is necessary mainly due to structural characteristics, such as individual SMEs featuring a strong unified culture, but also since SMEs are such a diverse group. However, not all other pieces of advice are equally valid in all SMEs. Individuals looking to introduce QM into their companies should thus contemplate the characteristics that are dominant in their company and consider implementing the QM methodology based on these characteristics. 
The characteristic involving the SME lack of resources makes it impossible to do everything at once, which is why there is a need for Gradual Implementation of QM methods into a company. Realistic goals and pilot projects may also help mitigate obstacles stemming from a fire-fighting mentality in which rapid and concrete results are expected. This lack of resources (for example, monetary but also in terms of skills, such as internal change agents) is also the cause for emphasising Involvement of External Support. Employees in SMEs are often occupying multiple roles and have a direct influence on results, which is why the Involvement of Employees is necessary. Direct communication and other measures to accomplish this task may, however, be easier to achieve in SMEs than in large companies due to their oftentimes flat structures. Following this, since there often is a lack of specialisation and know-how, the Training of Employees is needed. Management Involvement is often emphasised in all QM research but is arguably even more important to SMEs which have strong managerial influence with only a single or a few individuals leading the company and a unifying culture that is often led by these few individuals. Finally, since SMEs are characterised by results-orientation, it is critical to have a Fact-Based Follow-Up of the QM initiative through benchmarking and the measurement of internal processes.

\section{Conclusion}

Based on a review of the literature, the purpose of this paper has been to identify critical factors for QM initiatives in SMEs. Based on 59 papers, a number of factors have been extracted and then grouped into six categories: Contextualisation, Gradual Implementation Using Realistic Goals, Involvement and Training of Employees, Involvement of External Support, Management Involvement, and Fact-Based Follow-Up. These factors are not all unique to SMEs but collectively, they are uniquely targeted towards SMEs. Considering the literature reviewed, the frameworks for QM in SMEs are scarce and there appears to be a need for further research leading to frameworks applicable to QM in SMEs. For example, this might be based on in-depth case studies of QM initiatives in SMEs in order to provide additional guidance for practitioners, as well as researchers. In these types of studies, the proposed categories of critical factors should be evaluated and refined. For practical planning (e.g. by SME managers or external actors) of QM initiatives in SMEs, the framework may be interpreted as advice (see Table 4 for an elaboration), the consideration of which points towards useful QM initiatives adapted to SME characteristics.

\section{References}

Abdul-Aziz, Z., Chan, J. F. L., \& Metcalfe, A. V. (2000). Quality practices in the manufacturing industry in the UK and Malaysia. Total Quality Management, 11(8), 1053-1064

Achanga, P., Shehab, E., Roy, R., \& Nelder, G. (2006). Critical success factors for lean implementation within SMEs. Journal of Manufacturing Technology Management, 17(4), 460-471

Ahire, S. L., \& Golhar, D. Y. (1996). Quality management in large vs small firms. Journal of Small Business Management, 34(2), 1-13

Ahlström-Söderling, R. (2003). SME strategic business networks seen as learning organizations. Journal of Small Business and Enterprise Development, 10(4), 444-454

Ahmed, S., \& Hassan, M. (2003). Survey and case investigations on application of quality management tools and techniques in SMIs. International Journal of Quality \& Reliability Management, 20(7), 795-826 
Anderson, J. C., Rungtusanatham, M., \& Schroeder, R. G. (1994). A Theory of Quality Management Underlying the Deming Management Method. The Academy of Management Review, 19(3), 472-509

Barratt, M., Choi, T. Y., \& Li, M. (2011). Qualitative case studies in operations management: Trends, research outcomes, and future research implications. Journal of Operations Management, 29(4), 329-342

Beheshti, H. M., \& Lollar, J. G. (2003). An empirical study of US SMEs using TQM. Total Quality Management \& Business Excellence, 14(8), 839-847

Bergman, B., \& Klefsjö, B. (2010). Quality: from customer needs to customer satisfaction (3:5 ed.). Lund: Studentlitteratur.

Boon, S., \& Ram, M. (1998). Implementing quality in a small firm: An action research approach. Personnel Review, 27(1), 20-39

Bridge, S., O'Neill, K., \& Cromie, S. (2003). Understanding enterprise, entrepreneurship, and small business. New York: Palgrave Macmillan.

Chandler, G. N., \& McEvoy, G. M. (2000). Human Resource Management, TQM, and Firm Performance in Small and Medium-Size Enterprises. Entrepreneurship: Theory \& Practice, 25(1), 43-57

Chileshe, N. (2007). Quality management concepts, principles, tools and philosophies: A valid methodology for deployment within UK construction-related SMEs. Journal of Engineering, Design and Technology, 5(1), 49-67

Claver, E., \& Tarí, J. J. (2008). The individual effects of total quality management on customers, people and society results and quality performance in SMEs. Quality and Reliability Engineering International, 24(2), 199-211

Danes, S. M., Loy, J. T.-C., \& Stafford, K. (2008). Business Planning Practices of Family-Owned Firms within a Quality Framework. Journal of Small Business Management, 46(3), 395421

Davig, W., Brown, S., Friel, T., \& Tabibzadeh, K. (2003). Quality management in small manufacturing. Industrial Management \& Data Systems, 103(2), 68-77

Dean, J. W., Jr., \& Bowen, D. E. (1994). Management theory and total quality: Improving research and practice through theory development. The Academy of Management Review, 19(3), 392-418

Demirbag, M., Tatoglu, E., Tekinkus, M., \& Zaim, S. (2006). An analysis of the relationship between TQM implementation and organizational performance: Evidence from Turkish SMEs. Journal of Manufacturing Technology Management, 17(6), 829-847

European Commission. (2008). Putting Small Businesses First. Retrieved from http://ec.europa.eu/enterprise/entrepreneurship/docs/sme_pack_en_2008_full.pdf.

Fening, F. A., Pesakovic, G., \& Amaria, P. (2008). Relationship between quality management practices and the performance of small and medium size enterprises (SMEs) in Ghana. International Journal of Quality \& Reliability Management, 25(7), 694-708

Gadenne, D., \& Sharma, B. (2009). An investigation of the hard and soft quality management factors of Australian SMEs and their association with firm performance. International Journal of Quality \& Reliability Management, 26(9), 865-880

Ghobadian, A., \& Gallear, D. N. (1996). Total quality management in SMEs. Omega, 24(1), 83106

Ghobadian, A., \& Gallear, D. N. (1997). TQM and organization size. International Journal of Operations \& Production Management, 17(2), 121-163 
Gunasekaran, A., Forker, L., \& Kobu, B. (2000). Improving operations performance in a small company: a case study. International Journal of Operations \& Production Management, 20(3), 316 - 336

Hansson, J., \& Klefsjö, B. (2003). A core value model for implementing total quality management in small organisations. The TQM Magazine, 15(2), 71-81

Hodgetts, R. M., Kuratko, D. F., \& Hornsby, J. S. (1999). Quality implementation in small business: Perspectives from the Baldridge Award winners. S.A.M. Advanced Management Journal, 64(1), 37

Hollander, E. D. (1967). The Future of Small Business. New York: Frederick A Praeger.

Hudson, M., Smart, A., \& Bourne, M. (2001). Theory and practice in SME performance measurement systems. International Journal of Operations \& Production Management, 21(8), 1096-1115

Jones, S. C., Knotts, T. L., \& Brown, K. L. (2005a). Selected Quality Practices of Small Manufacturers. The Quality Management Journal, 12(1), 41-53

Jones, S. C., Knotts, T. L., \& Brown, K. L. (2005b). Selected Quality Practices of Small Manufacturers. The Quality Management Journal, 12, 41-53

Khalid, S., Irshad, M. Z., \& Mahmood, B. (2011). TQM Implementation in Textile Manufacturing Industry to Success: Review and Case Study. International Business Research, 4(4), 242247

Kumar, M., \& Antony, J. (2008). Comparing the quality management practices in UK SMEs. Industrial Management \& Data Systems, 108(9), 1153-1166

Kuratko, D. F., Goodale, J. C., \& Hornsby, J. S. (2001). Quality practices for a competitive advantage in smaller firms. Journal of Small Business Management, 39(4), 293-311

Lee, C. Y. (2004). TQM in small manufacturers: an exploratory study in China. International Journal of Quality \& Reliability Management, 21(2), 175-197

Lee, G. L., \& Oakes, I. (1995). The pros and cons of total quality management for smaller firms in manufacturing: some experiences down the supply chain. Total Quality Management, 6, 413-426

Lewis, W. G., Pun, K. F., \& Lalla, T. R. M. (2006). Exploring soft versus hard factors for TQM implementation in small and medium-sized enterprises. International Journal of Productivity and Performance Management, 55(7), 539-554

MacInnis, D. J. (2011). A Framework for Conceptual Contributions in Marketing. Journal of Marketing, 75(4), 136-154

Martínez-Costa, M., \& Jiménez-Jiménez, D. (2009). The Effectiveness of TQM. International Small Business Journal, 27(1), 98-125

Neerland, H., \& Kvalfors, T. (2000). Practical experience with quality improvement in small companies. Integrated Manufacturing Systems, 11(3), 156-164

Pink, D. H. (2010). Drive: The surprising truth about what motivates us: Canongate.

Rahman, M. N. A., \& Tannock, J. D. T. (2005). TQM Best Practices: Experiences of Malaysian SMEs. Total Quality Management \& Business Excellence, 16(4), 491-503

Rahman, S.-U. (2001). Total quality management practices and business outcome: evidence from small and medium enterprises in Western Australia. Total Quality Management, 12(2), 201210

Rantakyrö, L. (2004). Still searching the best way... : a multiple-case study in small industrial organizations. Luleå: Luleå University of Technology. 
Robinson, A. G., \& Schroeder, D. M. (2006). Ideas are free: how the idea revolution is liberating people and transforming organizations. San Francisco: Berrett-Koehler Publishers.

Ryan, C., \& Moss, S. E. (2005). Total Quality Management Implementation: The "core" strategy. Academy of Strategic Management Journal, 4, 61

Rönnbäck, Å., \& Witell, L. (2008). A review of empirical investigations comparing quality initiatives in manufacturing and service organizations. Managing Service Quality, 18(6), 577-593

Salaheldin, S. I. (2009). Critical success factors for TQM implementation and their impact on performance of SMEs. International Journal of Productivity and Performance Management, 58(3), 215-237

Saraph, J. V., Benson, P. G., \& Schroeder, R. G. (1989). An Instrument For Measuring The Critical Factors Of Quality. Decision Sciences, 20(4), 810

Schroeder, R. G., Linderman, K., Liedtke, C., \& Choo, A. S. (2008). Six Sigma: Definition and underlying theory. Journal of Operations Management, 26(4), 536-554

Shahin, A., Arabzad, S. M., \& Ghorbani, M. (2010). Proposing an Integrated Framework of Seven Basic and New Quality Management Tools and Techniques: A Roadmap. Research Journal of Internatıonal Studies, November, 183-195

Singh, R. K. (2011). Analyzing the interaction of factors for success of total quality management in SMEs. Asian Journal on Quality, 12(1), 6-19

Sousa, R., \& Voss, C. A. (2002). Quality management re-visited: a reflective review and agenda for future research. Journal of Operations Management, 20(1), 91-109

Struebing, L., \& Klaus, L. A. (1997). Small businesses thinking big. Quality Progress, 30(2), 23

Sun, H., \& Cheng, T.-K. (2002). Comparing Reasons, Practices and Effects of ISO 9000 Certification and TQM Implementation in Norwegian SMEs and Large Firms. International Small Business Journal, 20(4), 421-442

Tannock, J., Krasachol, L., \& Ruangpermpool, S. (2002). The development of total quality management in Thai manufacturing SMEs: A case study approach. International Journal of Quality \& Reliability Management, 19(4), 380-395

Temtime, Z. T. (2003). The moderating impacts of business planning and firm size on total quality management practices. The TQM Magazine, 15(1), 52-60

Temtime, Z. T., \& Solomon, G. H. (2002). Total quality management and the planning behavior of SMEs in developing economies. The TQM Magazine, 14(3), 181-191

Thomas, A., \& Webb, D. (2003a). Quality systems implementation in Welsh small- to mediumsized enterprises: a global comparison and a model for change. Paper presented the Proceedings of the Institution of Mechanical Engineers, Part B: Journal of Engineering Manufacture. http://dx.doi.org/10.1243/095440503321628251

Thomas, A., \& Webb, D. (2003b). Quality systems implementation in Welsh small- to mediumsized enterprises: a global comparison and a model for change. Paper presented the Proceedings of the Institution of Mechanical Engineers, Part B: Journal of Engineering Manufacture.

van der Wiele, T., \& Brown, A. (1998). Venturing Down the TQM Path for SME's. International Small Business Journal, 16(2), 50-68

Yin, R. K. (2009). Case study research - design and methods (4th ed.). Los Angeles: Sage Publications. 
Yusof, S. R. M., \& Aspinwall, E. (1999). Critical success factors for total quality management implementation in small and medium enterprises. Total Quality Management, 10(4-5), 803809

Yusof, S. R. M., \& Aspinwall, E. (2000a). A conceptual framework for TQM implementation for SMEs. The TQM Magazine, 12(1), 31-37

Yusof, S. R. M., \& Aspinwall, E. (2000b). Critical success factors in small and medium enterprises: survey results. Total Quality Management, 11(4-6), 448-462

Yusof, S. R. M., \& Aspinwall, E. (2000c). Total quality management implementation frameworks: comparison and review. Total Quality Management, 11(3), 281-294

Yusof, S. R. M., \& Aspinwall, E. (2000d). TQM implementation issues: review and case study. International Journal of Operations \& Production Management, 20(6), 634-655 